\title{
Comments on Larry May, Limiting Leviathan
}

Stewart Duncan

[Version of 19 March 2014. For a special section of the Autumn 2014 issue of Hobbes Studies discussing May’s book.]

ABSTRACT: This paper discusses two aspects of Larry May's book Limiting Leviathan. First it discusses a passage in Leviathan, to which May draws attention, in which Hobbes connects obligation to "that, which in the disputations of scholars is called absurdity". Secondly it looks at the book's discussion of Hobbes and pacifist attitudes, with reference to Hobbes's contemporary critic John Eachard.

KEYWORDS: Hobbes, May, obligation, contradiction, Eachard, pacifism

I'm grateful for this opportunity to comment on Limiting Leviathan. One of the pleasures of studying Hobbes is the ability to engage with the work of people with a variety of academic backgrounds and approaches: philosophers and historians of philosophy, but also other historians, political scientists, literature scholars, and so on. And, most pertinently here, those with an interest in the law and Hobbes's views about it. The legal aspects of Prof. May's book manifest themselves in a variety of ways, two of which I'd like to draw attention to here to begin.

One is the introduction of particularly legal concepts, and the background they provide to aspects of Hobbes's discussion. I'm thinking here, for example, of the 
discussion of the concept of assumpsit, and the description of the development of views about third party beneficiary contracts. From this sort of discussion and contextualization I have, albeit as an outsider to such matters, learned a lot, and I'm very grateful for it. The second is the extended discussion of Hobbes's Dialogue between a Philosopher and a Student, of the Common Laws of England. That is, as May says, a text that has not received a huge amount of discussion. It is a fascinating text, and the discussion of it forms a fascinating and insightful part of Limiting Leviathan.

Having praised those two central virtues of the book I'm now, I admit, going to talk about other things. The first relates to the account of Hobbes's political philosophy in the early chapters. Here I focus on the connection Hobbes makes, and May finds important, between obligation and contradiction. The second concerns the discussion of chapter 10, on "The Attitude of Pacifism".

\section{I.}

In the general account of Hobbes's political philosophy in the early chapters of Limiting Leviathan, May draws attention to a passage in chapter 14 of Leviathan where Hobbes connects obligation to contradiction. As he says:

At one crucial point in Leviathan, Hobbes constructs an analogy between being obliged to give the correct answer to a mathematical or logical problem, and being bound to follow the law of nature concerning the keeping of one's promises.

So that injury, or injustice, in the controversies of the world, is somewhat like to that, which in the disputations of scholars is called absurdity. For as it is there called an absurdity, to contradict what one maintained in the 
beginning: so in the world, it is called injustice, and injury, voluntarily to undo that, which from the beginning he had voluntarily done.

In both cases, one is bound in the sense that one risks self-contradiction - that is, the rejection of what one has a will to do - if one does not assent to the correct answer or action (33).

This connection between the two cases is then said to create significant bridges between parts of Hobbes's philosophy: between metaphysics and ethics, and between moral philosophy and political philosophy. Elsewhere, pointing to the same passage, May highlights the connection to absurdity to bring out how "Hobbesian self-imposed limitations, grounded in natural of divine law, may be binding in ways that one might not expect" (15).

This passage that connects injustice to absurdity is certainly a notable one, for multiple reasons. It is also, I'd like to suggest, a rather puzzling one.

The passage gains some notability from its textual location. It is in chapter 14 of Leviathan, the chapter that discusses the first two laws of nature. Moreover, it is in the very paragraph in which Hobbes tells us what it is to be obliged and what injustice is. These are absolutely central texts for Hobbes's moral and political philosophy. Indeed, they are texts that one might hope would help solve a serious puzzle in understanding Hobbes's work: what he thinks the origin of normativity is. At this point in Leviathan, Hobbes moves from telling us the way things are to the way they ought to be, from telling us what people to do telling us what they are obliged to do. A wide variety of 
explanations have been offered of where Hobbes sees obligation as coming from, but it would surely be natural to hope that he might tell us here. ${ }^{1}$

I fully agree that this seems to be a really important passage, at least in the version of Hobbes's view that was presented in Leviathan. ${ }^{2}$ I find myself puzzled, however, by how the argument is supposed to work here. Let me try to explain, at least, what I find puzzling about it.

Injustice, Hobbes tells us, is like contradiction, like claiming $\mathrm{p}$ at one point and not-p at another. However, claiming $p$ at one point and not-p at another is not necessarily problematic. Yes, there is such a thing as problematically contradicting yourself. There is also such a thing as changing your mind, which is not necessarily blameworthy. Indeed, changing your mind may be praiseworthy. So what distinguishes the bad cases from the good cases? And how does that carry over, if it does, into the moral cases? Why is voluntarily undoing that which you previously did, on the moral side, like the problematic case in which you contradict yourself, rather than like the neutral or positive case in which you change your mind?

Sticking to the side on which there is absurdity and contradiction, notice that Hobbes does not just invoke any old contradiction. Instead he invokes contradiction "in the disputations of scholars". This is not just an archaic-sounding way of talking about all scholarly disagreement. Nor is it, I suggest, simply a matter of restriction to logical and

\footnotetext{
${ }^{1}$ Cf. D. Gauthier, The Logic of Leviathan: The Moral and Political Theory of Thomas Hobbes (Oxford: Clarendon, 1969), 41-2.

${ }^{2}$ Similar passages in The Elements of Law (XVI.2) and De Cive (De Cive III.3) connect absurdity to injury and the absence of right, but perhaps not in the same way as in Leviathan. See Luc Foisneau, "Leviathan's Theory of Justice," in T. Sorell and L. Foisneau (eds.), Leviathan after 350 years (Oxford: Oxford University Press, 2004), particularly 114-5, on Hobbes's use of "the argument that injury is absurdity" in the Elements of Law as an argument that you ought to keep your covenants.
} 
mathematical problems. Rather, there were such things as disputations, which were formal, organized events with their own rules. ${ }^{3}$

Just how disputations worked is a complex issue. What is important here, however, is that in Hobbes's example, contradiction is bad within the disputation, because that's what the rules of the disputation say. This is not a context in which changing your thesis is to be praised.

Thus on the absurdity side of the comparison, contradiction is bad in a certain context, the context of the disputation. Thinking through the analogy, is there also a certain context on the moral side in which voluntarily undoing that which you previously did is bad? What, if anything, distinguishes cases of injury from cases in which you blamelessly change your mind? What is the analogy to the context of the disputation?

I find it hard to see what the analogous context might be might be. Perhaps this is just my lack of imagination, but this is quite puzzling. If there is such a context, this will serve to limit where there is injury and injustice. But if there is none, then injury turns out to be rather unlike contradiction (rendering the comparison fairly superficial). I don't want to suggest that this is a giant or fatal flaw in May's book. Far from it. But as he is among those who find this passage very important, I do wonder what he might have to say by way of more detailed illumination of the comparison. How, exactly, does Hobbes manage to build these bridges?

\footnotetext{
${ }^{3}$ On disputations in general, see for example A. J. Novikoff, "Toward a Cultural History of Scholastic Disputation," American Historical Review, 117 (2012), 330-64. For an introduction to the rules of one sort of disputation, disputations de obligationibus, see P. V. Spade and M. Yrjönsuuri, "Medieval Theories of Obligationes," in E. N. Zalta (ed.), The Stanford Encyclopedia of Philosophy, Fall 2013 Edition [http://plato.stanford.edu/archives/fall2013/entries/obligationes/].
} 


\section{II.}

Chapter 10 of Limiting Leviathan, "The Attitude of Pacifism", is devoted to arguing "against the common attempt to portray a 'Hobbesian' position as involving the rationality of having pro-war attitudes" (224). Here May refers briefly to criticisms made of Hobbes by John Eachard (224), which had been discussed earlier in Limiting Leviathan (45-6). There May draws particular attention to a passage from the "Preface to the Reader" of Eachard's Mr. Hobbs's State of Nature Considered. Eachard finds, in a way, that Hobbes's philosophy has too violent an attitude - for Hobbes says people must fight when we ought to say at most that they might.

Thou mightest possibly expect ... that I should ... have answered to Mr. Hobbs's sixth Article, Cap. 1. de Cive. Wherein he saies, that a great and necessary occasion of quarrelling and war is, that several men oftimes have a desire to the same thing; which thing if it happens not to be capable of being divided, or enjoyed in Common, they must needs draw and fight for't: Instead of which, he should have said; if these men chance to be mad, or void of reason, it is possible they may fight for't: For being that every one of them have an equal right to this same, that is in controversie, they may either compound for it as to its value, or decide it by Lot, or some other way that reason may direct (which is a Law of reason and humane Nature, and not meerly positive, because it is in Law Books. $)^{4}$

\footnotetext{
${ }^{4}$ John Eachard, Mr. Hobbs's State of Nature Considered (London, 1672). Available from Early English Books Online [http://gateway.proquest.com/openurl?ctx_ver=Z39.882003\&res_id=xri:eebo\&rft_id=xri:eebo:citation:99895552]. Hobbes had said that "the most frequent cause why men want to hurt each other arises when many want the same thing at the same time, without being able to enjoy it in common or to divide it. The
} 
Hobbes finds a necessity of things being decided by violence where, one might think, there is merely a possibility. ${ }^{5}$ Eachard also, however, asserts that one ought to act, in the described situation, in a way that is directed by reason, "which is a Law of reason and humane Nature". And that, without going into the complexities of the issue, is something that Hobbes might well find congenial. After all, a law of nature for Hobbes is itself "a Precept, or generall Rule, found out by Reason". ${ }^{6}$ So though we should not go so far as to say that Eachard and Hobbes agreed here - Eachard clearly found the humans in Hobbes's image of the state of nature to be overly violent characters - there is more common ground than Eachard perhaps allows in his Preface.

Eachard though, sees Hobbes as accepting, if not perhaps encouraging, violence. But accepting that humans have violent tendencies, even violent natures, is compatible with encouraging them to be more peaceful. Indeed, is this not a reasonable general way to think about Hobbes was doing?

Thus, leaving Eachard and speaking a little more generally, the idea that Hobbes promotes the possession of some sort of pacifist attitude appears both interesting and plausible to me. After all, just at first sight, we see Hobbes talk of the "first, and Fundamentall Law of Nature; which is, to seek Peace, and follow it". ${ }^{7}$ And, again without delving into complexities, this appears not necessarily inconsistent with a belief that people in the state of nature will tend to resolve disputes violently.

consequence is that it must go to the stronger. But who is the stronger? Fighting must decide". T. Hobbes, On the Citizen, ed. And tr. R. Tuck and M. Silverthorne (Cambridge, Cambridge University Press, 1998), 27

${ }^{5}$ A parallel text in Leviathan is a perhaps more subtle than that from De Cive, but still talks of men who "endeavor to destroy, or subdue". Leviathan, edited by N. Malcolm (Oxford: Clarendon, 2012), 61.

${ }^{6}$ Leviathan, 64. See May's discussion of the relation of reason to virtue (226).

${ }^{7}$ Leviathan, 64. 
At least, I want to say, May seems exactly right that it is not Hobbesian to promote the possession of aggressive attitudes. If there is a sort of character development being suggested by Hobbes, it is away from the overly aggressive character suggested to belong to humans in the state of nature, towards one that is guided by the better use of reason. Again, after all, peace is one of the key goals.

However, I would ask whether it is Hobbesian to think we ought to develop distinctively pacifist attitudes, even with that goal. What about, rather, nervous and watchful ones? There seems, at any rate, to be some ground between promoting pacifist attitudes, even the somewhat limited ones that May attributes to Hobbes's view, and promoting aggressive and warlike attitudes.

For a final thought about Hobbes and pacifist attitudes, I turn to Hobbes's Dialogue between a Philosopher and a Student, of the Common Laws of England, to note an example that is used in passing there. The philosopher character mentions "King $E d w$. 3d. and King Henry the 5th", describing them as "Kings of whom we Glory now, and think their Actions great Ornaments to the English History". ${ }^{8}$ Whatever exactly Hobbes thought they were famous or admirable for, it seems a little curious to think of Henry V, in particular, as embodying or recommending pacifist attitudes. ${ }^{9}$ This is only a passing remark, and not part of any political theorizing, but it does suggest a not especially pacifist attitude on Hobbes's part.

${ }^{8}$ A Dialogue between a Philosopher and a Student, of the Common Laws of England, in Thomas Hobbes, Writings on Common Law and Hereditary Right, ed. A Cromartie and Q. Skinner (Oxford: Clarendon, 2005), 24.

${ }^{9}$ On the distinct issue of whether Shakespeare's Henry $V$ contains pacifist themes, see S. Marx, "Shakespeare's Pacifism," Renaissance Quarterly, 45 (1992), 49-95. He comments on Henry $V$ : "But while the articulation of the militarist viewpoint becomes increasingly emphatic and sophisticated by the time of Henry $V$ in 1599 , its margin of victory over pacifist critiques narrows almost to a standoff' (59). 